Fig. 4 again shows the island in its winter garb, and is from a drawing made by Lieut. Ring, R.N., when commanding the sealer Capella.

"We have Sars's crater, on the slope shelving to wards Cape North-East ; we see, too, the great glaciers on the north side, also Cape North-West and Muyen's Cross Cape, in a line with the point of view; and the low tract of the island, with the heights of the southern part, are boldly defined in the picture. The crater of Beerenberg, with its sunken edge on the north side, is also seen, and lower down a huge, cauldron-shaped depression, from which the great northern glaciers take their origia."

Some very interesting mineralogical specimens were brought from Jan Mayen, on which Mr. H. Reusch, of the Norwegian Geological Survey, reports. We reproduce illustrations of four specimens of olivine in basalt.

In Fig. 5 the surrounding rock exhibits a remarkably fine granulation in immediate proximity to the çrystals, which it pierces in sac-like ramifications. In Fig. 6 discoloured glass is seen piercing the crystal from the surrounding rock, which has a fine granulation. In Fig. 7 the surrounding base is finely granulated. At the top of the figure is seen basalt of the dominant degree of granulation. Discoloured glass pierces the crystal from the rock surrounding it. In Fig. 8 the iron ore occurring as rod-shaped corpuscles has a definite position towards the crystal of olivine.--Magnified 360 diameters.

Dr. Mohn concludes his instructive account of the geography of this fruitful expedition by some brief observations on Bear Island and Spitzbergen, at various points of which the Voringen touched.

\section{SCIENCE AT CAMBRIDGE}

WE understand that Dr. M. Foster, who, upon his appointment as Professor of Physiology at Cambridge, ceased to be Prælestor at Trinity College, addressed to the Master of Trinity the following letter, which perhaps may interest those of our readers who are not acquainted with the peculiar organisation of our old Universities.

Shelford, Cambridge, July 28, 1883

My DEAR MASTER,-The University having done me the honour to appoint me to the newly established Chair of Physiology, my connection with the College as Prælector comes to an end, though I rejoice that I am still counted among the Fellows of the Society. I cannot let this opportunity pass without making some attempt to thank you, and through you the College, for all you have done for me during the thirteen years of my Prælectorship. You called me, a comparatively unknown young man, to the College in I870; you not only at once gave me leave to follow out my own views as to what I ought to do, but from that time onward have constantly supported me, not simply with cordial approbation, but also with most material assistance.

I have reason to believe that many persons not conversant with the orgarisation and working of the University, are under the impression that the necessary expenses which my work has entailed hive been provided out of University funds. But I am sure that the authorities of the University would be the last to wish that anything done by the College should be considered as done by the University. And as a matter of fact, when I say that I was allowed the use for four years of one room, and for ten years of two rooms, in the University buildings, and that during the last three years I have enjoyed the advantages of the admirable laboratory which has been built for me, with use of gas and water, I have mentioned all that $I$ have received from the University, with the exception of grant of microscopes to the late Prof. Balfour and myself in common. Not only my own remuneration has come from the Colle ${ }^{2}$, but all the really large expenditure involved in my teashing physi- ology, save what has been met by the fees of the students, has been provided for in one way or another by the College.

At the outset the College gave me a large grant of money for apparatus, and some years afterwards a second smaller grant. During the whole thirteen years I have received from the College an annual sum for the payment of my laboratory servants ; and for several years past two demonstrators (one at a comparatively high salary), as well as during the past year three assistant demonstrators, have been paid partly from the tuition fund of the College, partly by funds which, though furnished by private liberality, cannot be wholly dissociated from the College. I think I may fairly say that I have never asked anything of you in vain. I might add that what you have done for me did not prevent you from also assisting our lamented Balfour, working in a closely allied branch of science, or, upon his sat death, from affording material help in carrying on the work which he left behind through aid given to Mr. Adam Sedgwick.

Let me assure you that I fully appreciate all the College has done for me; but perhaps after all I feel still more keenly the sympathy and kindness with which as a stranger I was first received among you, and which have made the thirteen years of my Prælectorship the brightest as well as the best years of my life.

Yours ever truly,

M. FOSTER

\section{THE ISCHIA EARTHQUAKE}

A SLIGHT shock of earthquake occurred in Casamicciola at seven o'clock on Sunday morning, at the Gurgitello, where that of July 28 created the most ruin, but it was limited to that spot, and caused no damage. It is reported that a fissure a kilometre in length and thirty kilometres in depth has opened on the south-west flank of Mount Epomeo. The smo'ze ejected from the fumaroli at the summit of the mountain has considerably diminished in quantity. The Naples Academy of Sciences has appointed a Commission to investigate the telluric conditions of Ischia.

The following communication from the Times correspondent at Rome is important :-

"From a second report made by Prof. Michele Stefano di Rossi, head of the Central Geodynamic Observatory at Rome, to the Minister of Agriculture, on the phenomena connected with the earthquake in Ischia, it appears that not only were there for some days beforehand very distinct premonitory signs at Casamicciola of the impending catastrophe, but that throughout the peninsula forewarnings, identical in character, were numerous and widespread. On the island of Ischia there was an extraordinary increase in the temperature of the thermal waters and in the violence of the fumaroli (i.e. the natural smoke funnels) at the spot called Monte Cito. These phenomena were noticed eight days before the catastrophe occurred. On these important points the evidence which Prof. di Rossi obtained is abundant. There is less conclusive testimony concerning the shrinking and consequent scarcity of the drinking water in the wells. But he has absolutely certified that, commencing from a period a fortnight anterior to July 28 , many slight shocks of earthquake, of almost daily recurrence, were felt, and subterranean rumblings were
heard. Phenomena identical with these preceded the earthquakes in Ischia in I828, I85 I, and I88I; and Prof. di Rossi emphatically states that had an observatory been established in Ischia after the earthquake of I88I, according to the advice he then gave, and the phenomena which manifested themselves at Cassamicciola from July 20 onwards been communicated to him at the Central Observatory in Rome, he would not have hesitated an instant in pointing out the imminent danger of an impending 
seismic disturbance. While the above-mentioned phenomena were occurring in Ischia, without their baing communicated to Rome, or even, for want of means, properly noted on the spot, the existence of unusual subterranean activity was simultaneously marked by the instruments in all the observatories on the mainland. That activity, though varying in intensity in different places, manifested a general and regularly progressive augmentation. Slight shocks of earthquake were felt at various points. On July 25 the Solfatara of Albano, on the extinct Latin volcanoes on the southern side of the Roman Campagna, sent forth sounds never before remarked. Cn the same day a widely extended earthquake, reaching from Cosenza to Catanzaro, occurred in Calabria. On Friday, the 27 th, the hissing noises from the Solfatara of Albano were so acute that the people did not dare to draw the sulphur water for those who needed it, and simultaneously the seismic instruments at $\mathrm{Pe}$ saro registered severe oscillations, At Vesuvins on the evening of Friday, the 27 th, shocks were felt, with an augmentation of activity. There were shocks at Latera, upon the Ciminian volcanoes, and shocks at Perugia. On the afternoon of the 28th renewed activity was manifested at Pesaro and at Fermo; and in short the observations during that afternoon of general calm throughout the peninsula gave indications of a vast subterranean disturbance, extending as far as all Umbria, the district of Viterbo, and the Marches.

"The direction of these extended movements was everywhere identical with those at Casamicciola-namely, from north to south, and from east to west. At the same time also, on the morning of the $28 \mathrm{th}$, the flow from the principal source of the sulphur streams, near Tivoli, showed a considerable diminution; while simultaneously an increased quantity of carbonic acid gas was given forth. The regular observations at Bologna, at Pisanello, near Piacenza, and at Rome, showed that there was a distinct lowering in the levels of the wells before July 28 , and as marked a rise after that date. These facts confer increased credibility on the imperfect evidence of there having been a deficiency of water in the wells at Casamicciola. Moreover, on the morning of Sunday, the 29th, the usually very cold waters of the Solfatara of Albano were in a builing state. The intimate connection between these phenomena on the peninsula and the catastrophe in Ischia is more than evident, and their distinct dynamic and volcanic character absolutely excludes the idea of a mere local sinking in the level."

\section{NOTES}

Telegrams from Drontheim to Vienna announce that the members of the Austrian expedition to Jan Mayen have arrived there safe and well, after an absence of six months. This was one of the circumpolar observing parties, and during the year's residence on Jan Mayen neither officers nor men suftered from scurvy or other disease. The chief of the expedition telegraphs to the Geographical Society of Vienna that they have made "perfect observations, rich collections, and taken geodetic and phutographic views of the island."

DURING the coming year, we learn fiom Science, experiments will be made at the physical laboratory of Johns Hopkins University with a view to. aid in establishing an in ernational unit of electrical resistance. The experiments will be carried on under the direction of Prof. Rowland, with an appropriation from the Government of the United States. The results will be communicated to the International Commission of Electricians meeting in Paris.

Dr. Robert Moffat, the famous African missionary, has died at the advanced age of eighty-seven years. He was among the first to show the way to Central South Africa, and added not a little to our knowledge of the Bechuanas and other tribes south of the Zambesi. He was Livingstone's father-in-law, and the special direction of the great missionary-traveller's African work was to a considerable extent due to Moffat's example and advice.

THE Ninth Annual Conference of the Cryptogamic Society of Scotland will be held at Dumfries on September Ir, I 2, and 13. Fellows who purpose attending the Conference are requested to communicate with the local Secretary, Mr. J. Rutherford, Jardington, Dumfries.

THE statue of the brothers Montgolfier was unveiled at Annonay on Monday, as part of the ceremonies commemorative of the centenary of the inventors of balloons. M. de Fonvielle writes to us from Annonay, August 12: "This celebration has been organised merely by private exertions in continuation of the banquet given by the Académie d'Aërostation of Paris on November, 1882, to commemorate the centenary of the first private experiment tried by Joseph Montgolfier at Avignon in his rooms. A local committee was formed in Annonay under the presidency of M. Séguin, the eldest son of Marc Séguin, Member of the Institute, a nephew of the Montgolfier to whom is attributed the creation in France of tubular boilers and metallic bridges. M. Henry Vidon of Annonay was appointed general secretary. The exertions of the Committee were very successful, and about 40:0l. were collected, principally in the immediate vicinity of Annonay and at Paris; foreign subscriptions were very few. It was decided to erect on the Place des Cordeliers, where the first experiment took place on June $5,1_{7} 8_{3}$, a statue representing the two brothers inventing the 'Montgolfière.' The plaster cast has been executed, and will be inaugurated tomorrow before a large audience. The ceremony will begin at two o'clock with a speech delivered by M. Séguin, after which a small Montgolfière will be sent up from the exact spot where the first experiment took place. On Saturday an aëronautical ascent was made from the Champs de Mars with a small balloon of 3000 cubic feet, the largest that the gas establishment could fill without inconvenience."

IN the just published parts 4 and 5 of his "Abbildungen von Vogelskelettes," Dr. Meyer, of Dresden, proves that the Notornis from the South Island of New Zealand belongs to a differe species from that from the North Island-Notornis mantelliand he names the former $N$. hochstetteri. It is known that Prof. Owen foundea on some fragments of the skull and the bones from the North I-land in the year 1848 the genus Notornis, and that be called the species, without then knowing a skin, $N$. mantelli, after the discoverer. The two skins, which were figured by John Gould in the years 1850 and 1869 , and which now adorn the galleries of the British Museum, came from the South Island, and were identified $\mathrm{w}$ ith the bones from the North Island. The Dresden Museum having acquired the skin and skeleton of a specimen of Notornis hunted in the year 1879 on the South Island-all three specimens were procured from within a range of ninety miles-Dr. Meyer compared his skeleton with Prof. Owen's life-size figures in the Transactions of the Zoological Scciety, and found them to be different, which fact is not to be wondered at, as New Zealand has proved to be very rich in species of flightless birds, and as the Notornis fragments came from another island than the three skins and the skeleton, perhaps Notornis became extinct on the North Island, whereas it still survives in certain parts of the South Island. Dr. Meyer is of opinion that if the bones and the skull had been taken out of the skins preserved in the British Museum, one would have known already in the year $185^{\circ}$, or at least in 1869 , that they differed from the Notornis mantelli fragments of the North Island. The name of those skins, therefore, must be altered, according to Dr. Meyer to $N$. hochstetteri. Dr. Meyer has figured the skeleton of N. mantelli in plates $34-37$ of his work. 